\title{
Adolescent Social Emotional Health, Empathy, and Self-esteem: Preliminary Validation of the Lithuanian Version of the SEHS-S Questionnaire
}

\author{
Ala Petrulyte $\dot{a}^{\mathrm{a}}$, Virginija Guogiené ${ }^{\mathrm{b}}$, Vaiva Rimiene $\dot{\mathrm{a}}^{\mathrm{a}}$ \\ ${ }^{a}$ Vytautas Magnus University, Vilnius, Lithuania \\ ${ }^{b}$ Švenčionèliai progymnasium, Vilnius, Lithuania \\ ${ }^{\star}$ Corresponding author. E-mail: ala.petrulyte@vdu.lt
}

Background. The priority for today's educational psychologists in Lithuanian schools is to promote psycho-educational activities aimed at fostering children's well-being. School psychologists are to provide services for, and consult with, children and adolescents with mental health challenges, in order to facilitate their transitions to positive developmental trajectories. Therefore, it is important to test the construct validity of the adolescent social emotional health survey (SEHS-S) in a Lithuanian sample.

Objective. To investigate the social emotional health, empathy, and selfesteem of a Lithuanian adolescent sample using the adolescent Social Emotional Health Survey (SEHS-S), as well as to perform regression and confirmatory factor analysis.

Design. We used the Social Emotional Health Survey-Secondary (SEHS-S) (Furlong et al., 2014), the Interpersonal Reactivity Index (IRI) (Davis, 1980), and the Rosenberg Self-Esteem Scale (SES) (M. Rosenberg, 1989). The sample was comprised of 935 students (12-18 years old) from various Lithuanian schools: 482 boys and 453 girls.

Results. The self-esteem of the adolescent boys was higher than that of the adolescent girls. A positive correlation between the adolescents' social emotional health and their self-esteem and empathy was identified. The strongest predictors of the adolescents' social and emotional health included empathic concern, self-esteem, and perspective-taking. The confirmatory factor analysis confirmed the validity of the structural model of the Lithuanian version of the SEHS-S survey.

Conclusion. The findings of the regression and confirmatory factor analysis supported the use of the SEHS-S as a valid and reliable instrument for mental health research with Lithuanian adolescents. School psychologists will be able to use the Lithuanian version of SEHS-S survey to monitor adolescent social emotional health.

Keywords: junior and senior adolescents in Lithuania; age and gender differences; social emotional health survey(SEHS-S); empathy and self-esteem; correlation analysis; regression analysis; confirmatory factor analysis 


\section{Introduction}

At present psychologists working in Lithuanian schools have been encountering increasing rates of various dependencies and suicide, a growing number of bullying incidences, and more instances of adolescent behavioral and emotional problems. Currently educational psychologists have been prioritizing psycho-educational and preventive activities targeted at the emotional and social well-being of children. Some scholars (Kalpokiené, 2005; Ramanauskienè, Matulioniené, \& Martinkiené, 2002; Valantinas, 2009; Petrulytè \& Guogienè, 2018) have stated that adolescent mental health has been mainly investigated from the deficit-oriented perspective, i.e., the investigated factors are related to the youth's problems, various impairments, or related risks. It is particularly relevant to conduct research on the positive development of adolescents, paying specific attention to their ability to address the crises of psychosocial development in adolescence. Strengths developed in adolescence lead to an increased sense of happiness and improvement in their academic achievements (Park \& Peterson, 2008). The more strengths an adolescent gains, the more positive development that individual exhibits.

The present research study was carried out from the perspective of a positive psychological and holistic approach to mental health, which focuses on the emotional social health domains of the family, the school, and peers. Our approach treats adolescents' emotional and social health as a multi-dimensional construct, which embraces a combination of psychological strengths, or positive dispositions possessed by an individual: belief-in-self, belief-in-others, emotional competence, and engaged living (Furlong, You, Renshaw, Smith, \& O'Malley, 2014; Furlong, 2015). The concepts of adolescent social and emotional health include the adolescent's relations with family, school, and peer group, and the formation of a sense of identity together with self-respect and belief-in-self, not excluding their interaction and synergy. Scientific research conducted in the USA, Australia, Japan, Korea, and Turkey showed the model of social and emotional health to be appropriate (You, Furlong, Felix, \& O'Malley, 2014; Furlong, 2015). Our surveys revealed that the construct of social emotional health and strengths is interrelated with a high level of mental health, psychological resilience, and well-being. The value of enhancing the mental health of children and adolescents has been prioritized all over the world.

Over recent years M. Furlong has been the principal investigator in theoretical and practical research studies striving to design and implement the use of a universal and convenient psychometric tool for predicting the social emotional health of adolescents (Furlong et al, 2014; Furlong, 2015). We are partners at the international "Project CoVitality", a school-based mental wellness and thriving student development initiative (Project CoVitality, 2018). More than 20 countries worldwide have been applying the Social Emotional Health Survey (SEHS) to evaluate adolescents. The social emotional measures of adolescents positively correlate with measures of subjective well-being, life satisfaction, and the Big 5 personality constructs; they are negatively correlated with measures of internal emotional distress and involvement in-risk behavior. The Social Emotional Health Survey System includes three conceptually-linked measures that assess the core psychological and social mindsets associated with positive youth development from childhood through the post-high 
school transition (primary, secondary, and higher education). All three SEHS measures assess the general construct called "CoVitality" (Project CoVitality, 2018).

A large number of researchers refer to empathy as a relevant aspect of social emotional health. Our study approaches empathy as a multi-dimensional construct, which embraces emotional and cognitive processes (Davis, 1980; Batson, 2009; Decety \& Cowell, 2014). A high level of empathy in an adolescent creates favorable conditions for that adolescent to express positive emotions and is a signal of prosocial behavior (Pukinskaitė \& Guogienè, 2010).

The positive correlation between adolescents' emotional competence and various aspects of empathy has been previously identified (Petrides, Frederickson, Sangareau, \& Furnham, 2006; Hoffman, 2000; Kradin, 2005; Carr \& Lutjemeier, 2005, and others). Adolescent girls' understanding of their own feelings, their playfulness, and their ability to easily establish conversation and communicate with people more frequently, as well as the level of girls' empathy, are greater than those of boys (Strayer and Roberts, 2004; Katyal \& Awasthi, 2005; Shulte-Rüther, Markowitsch, Shah, Fink, \& Piefke, 2008; Žukauskienè, Malinauskienè, \& Erentaitè, 2011). Petrulyte \& Guogiene (2018) found that empathy is higher among senior adolescents (16-18 years old) compared to younger ones (12-15 years old), and in the group of girls compared to boys.

Positive self-esteem is of particular importance to adolescent well-being, and is linked to better social relations and higher levels of academic achievement (Bos, Muris, Mulkens, \& Schaalma, 2006), emotional intelligence (Schutte, Malouff, Simunek, Hollander, McKenley, \& Hollander, 2002; Žukauskienè, et al., 2011), and lower levels of emotional problems (Dutton \& Brown, 1997). Self-esteem in adolescence becomes a motivating factor and encourages an adolescent to act and seek self-realization.

The research studies on the strengths of adolescents' positive development, and adolescents' social emotional health, empathy, and self-esteem are few, and the above-mentioned dimensions can be successfully developed. The results of the present study will provide additional evidence about the utility of the SEHS-S model in Lithuania, and will contribute to cross-cultural research on adolescent social emotional health.

\section{Objective}

The main goal of our research was to investigate the social emotional health of Lithuanian adolescents and its links with their empathy and self-esteem, and to obtain additional evidence about the utility of the SEHS-S model in a Lithuanian sample.

The specific objectives of the research were:

1. To investigate and compare the self-esteem of adolescents in Lithuanian groups of younger (12-15 years old) and senior (16-19 years old) adolescents, as well as to compare that of girls and boys.

2. To investigate the links of adolescents' dispositions of social emotional health with empathy and self-esteem.

3. To carry out a regression analysis on adolescents' social emotional health, empathy, and self-esteem.

4. To perform a confirmatory factor analysis of adolescent social emotional health in a Lithuanian sample. 


\section{Methods}

\section{Participants}

Our sample was comprised of 935 adolescents from secondary schools in various Lithuanian regions (cities and districts): 483 junior adolescents (12-15 years old) and 452 senior adolescents (16-18 years old); 482 boys and 453 girls.

\section{Procedures}

The Social Emotional Health Survey-Secondary (SEHS-S) ( Furlong et al., 2014). This questionnaire survey includes a wide range of social emotional psychological dispositions associated with the positive development of young people. The construct validity of this questionnaire was confirmed after a factor analysis of its invariance in groups based on sociocultural and gender principles (You et al., 2015). The permission to use the questionnaire was granted to A. Petrulyte and V. Guogiené. The double translation was done by A. Petrulytė and J. Bagdonavičiūtè.

The questionnaire consists of four dispositions/scales: belief-in-self, belief-inothers, emotional competence, and engaged living. Each disposition embraces three unique sub-scales of mental health. The belief-in-self consists of self-efficacy, selfawareness, and persistence; the belief-in-others comprises school support, peer support, and family support; emotional competence consists of emotion regulation, empathy, and behavioral self-control; and engaged living embraces gratitude, zest, and optimism.

This instrument (SEHS-S) was validated using samples of students from California (Furlong et al., 2014; You et al., 2015), Korea (Lee, You \& Furlong, 2015), and Japan (Ito, Smith, You, Shimoda, \& Furlong, 2015). M. Furlong emphasizes that this research is directed toward the optimal exploration of human functions on the basis of the hypothesis that the combination of the first-order positive psychological dispositions (belief-in-self, belief-in-others, emotional competence, and engaged living) builds a second-order synergic meta-construct of "covitality", which is a good tool for understanding the quality of teenagers' and youth's lives, as well as predicting their success and well-being now and in later life (Furlong et al., 2014).

The SEHS-S questionnaire includes 36 items. The students' self-reports are completed using a four-point scale $(1=$ not at all true of me; $2=$ a little true of me; 3 = pretty much true of me; and $4=$ very much true of me). The following are examples of SEHS-S items: "I enjoy reading books;" "I usually expect to have a good day." The internal reliability of the results from the Lithuanian adolescent group (Cronbach's alpha) is presented in Table 1.

Table 1

Cronbach's alpha indicators of SEHS-S constructs in the Lithuanian adolescent group.

\begin{tabular}{lc}
\hline \multicolumn{1}{c}{ SEHS-S constructs } & Cronbach's alpha \\
\hline Belief-in-self & .73 \\
Belief-in-others & .76 \\
Emotional competence & .73 \\
Engaged living & .85 \\
General index & .80 \\
\hline
\end{tabular}


Interpersonal Reactivity Index (IRI), (Davis, 1980). This scale investigates various aspects of empathy and evaluates emotional reactions to the negative experiences of other people. The scale consists of 28 items. The respondents were asked to rate every item on a 4 -point scale (from 0 to 4 ) in respect to their suitability for characterization of own attitude and feelings. The respondents evaluated the statements while the supervisor was reading additional instructions. The scores of the sub-scales were calculated and the evaluations of all 7 items added up.

The scale of Interpersonal Reactivity Index (IRI) consists of four sub-scales that aim to evaluate different aspects of empathy:

1. Empathic concern scale. This scale assesses emotional empathy, i.e., the ability to feel compassion for others, or express tenderness toward them;

2. Perspective-taking scale. The scale establishes the cognitive aspect of empathy, i.e., the ability to understand and adopt the attitude of other people;

3. Personal distress scale. This scale evaluates the ability to experience distress and discomfort in reaction to the distress of others;

4. Fantasy scale. This scale evaluates the ability of respondents to transpose themselves imaginatively into the feelings of others.

The sum of the sub-scales of perspective-taking and empathic concern makes up the index of empathy. The author M.H. Davis granted permission to use the Scale of Interpersonal Reactivity Index to V. Guogiene. The internal reliability of the scores of the Lithuanian adolescent group (Cronbach's alpha) is as follows (see Table 2).

Table 2

Cronbach's alpha indicators of empathy (IRI) in the Lithuanian adolescent group

\begin{tabular}{lc}
\hline \multicolumn{1}{c}{ IRI constructs } & Cronbach's alpha \\
\hline Empathic concern & .62 \\
Perspective-taking & .67 \\
Personal distress & .58 \\
Fantasy & .66 \\
Empathy index & .77 \\
\hline
\end{tabular}

Rosenberg Self-Esteem Scale (RSE). M. Rosenberg (1989) defined global selfesteem as the overall attitude one has toward oneself. High self-esteem entails the belief that one is "good enough," whereas low self-esteem is associated with selfrejection and a general lack of self-respect. There are 10 RSE items with a 4-point rating scale. Cronbach's alpha coefficients for scores based on the 10 Rosenberg items are usually above .80 , and values above .90 have been reported in the literature (Boyle, Saklofske, \& Matthews, 2014). Self-esteem is positively correlated with psychological well-being and life satisfaction. These coefficients range from .30 to .60 or higher (e.g., Buhrmester et al., 2011; Robins et al., 2001; Rosenthal et al., 2011). The internal compatibility of the Lithuanian adolescent group's scores on self-esteem (Cronbach's alpha) is .72. 
Microsoft Excel 2003, SPSS (17.0 for Windows), and LISREL were used for data processing. To establish the link between the adolescents' social emotional health (SEHS-S), empathy, and self-esteem, correlation analysis was applied, and the coefficient of Spearman's rank correlation was calculated. The regression analysis was performed to examine the relationship and influence of independent variables on the dependent variable, i.e., on adolescent social emotional health (SEHS-S). The confirmatory factor analysis was carried out to verify the structure of the adolescents' social emotional health survey (SEHS-S) (Brown, 2015; Čekanavičius, 2009).

\section{Results}

In the previous research on adolescents' social emotional health (SEHS-S) conducted by the two authors of this article (Petrulyte \& Guogiene, 2018), statistically significant higher values in the dispositions of belief-in-self $(\mathrm{p} \leq 0.01)$, engaged living $(\mathrm{p} \leq 0.01)$, and general index of social emotional health were found among junior adolescents (12-15 years old) compared to senior ones (16-18 years old). Also, higher values of social emotional health (SEHS-S), dispositions of belief-in-others, emotional competence, and general index of social emotional health $(\mathrm{p} \leq 0.01)$ were observed among adolescent girls compared to boys. The indicators of adolescents' empathy (IRI) revealed statistically significantly higher values of the fantasy, personal distress, and empathy indices among senior adolescents $(\mathrm{p} \leq 0.000)$, compared to those of junior adolescents; the higher values of the indicators of empathic concern, perspective-taking, personal distress, and general index (IRI) $(\mathrm{p} \leq 0.000)$ were disclosed in the group of girls compared to that of boys.

However, in this research the comparison of self-esteem indicators of junior (12-15 years old) and senior (16-18 years old) adolescents did not show any statistically significant differences (see Table 3 ).

Table 3

Self-esteem of junior (12-15 years old) and senior (16-18 years old) adolescents (Mann-Whitney U test)

\begin{tabular}{cccccc}
\hline & Age & N & Mean Rank & Z & P \\
\hline \multirow{3}{*}{ Self-esteem } & $12-15$ years & 483 & 454.74 & & \\
& $16-18$ years & 452 & 482.17 & -1.55 & 0.120 \\
\hline
\end{tabular}

Statistically significant differences were identified in the values of self-esteem in the groups of girls and boys: the self-esteem of adolescent boys was higher than that of girls (see Table 4).

Table 4

Self-esteem of boy and girl adolescents (Mann-Whitney U test)

\begin{tabular}{cccccc}
\hline & Gender & $\mathrm{N}$ & Mean Rank & $\mathrm{Z}$ & $\mathrm{P}$ \\
\hline \multirow{3}{*}{ Self-esteem } & boys & 482 & 506.10 & & \\
& girls & 453 & 427.46 & -4.46 & 0.000 \\
\hline
\end{tabular}


The correlation analysis of the adolescents' social emotional health (SEHS-S) and empathy (IRI) allowed us to conclude that the scales of empathic concern, perspective-taking, and the empathy index positively correlate with all the dispositions of SEHS-S ( $\mathrm{p} \leq 0.01$ ), whereas fantasy (IRI) and personal distress (IRI) demonstrated positive correlations only with the scale of emotional competence (SEHS-S) $(r=0.22$; $\mathrm{p} \leq 0.01)$ (see Table 5).

Table 5

Correlations of the adolescents' social emotional health (SEHS-S) and empathy (N=935)

\begin{tabular}{lccccc}
\hline \multicolumn{1}{c}{ SEHS-S } & $\begin{array}{c}\text { Belief- } \\
\text { in-self }\end{array}$ & $\begin{array}{c}\text { Belief- } \\
\text { in-others }\end{array}$ & $\begin{array}{c}\text { Emotional } \\
\text { competence }\end{array}$ & $\begin{array}{c}\text { Engaged } \\
\text { living }\end{array}$ & $\begin{array}{c}\text { General } \\
\text { index }\end{array}$ \\
\hline Empathic concern scale & $0.17^{* *}$ & $0.27^{* *}$ & $0.49^{* *}$ & $0.23^{* *}$ & $0.35^{* *}$ \\
Perspective-taking scale & $0.13^{* *}$ & $0.17^{* *}$ & $0.45^{* *}$ & $0.23^{* *}$ & $0.30^{* *}$ \\
Fantasy scale & 0.00 & 0.05 & $0.22^{* *}$ & 0.01 & 0.06 \\
Personal distress & $-0.25^{* *}$ & -0.06 & $0.10^{* *}$ & $-0.12^{* *}$ & $-0.10^{* *}$ \\
Empathy index & 0.03 & $0.16^{* *}$ & $0.44^{* *}$ & $0.12^{* *}$ & $0.21^{* *}$ \\
\hline
\end{tabular}

Note. ${ }^{*} p \leq 0.000$

On the basis of the correlation analysis, it was established that adolescents' selfesteem significantly positively correlates with the following dispositions of social emotional health (SEHS-S): belief-in-self $(\mathrm{r}=0.38 ; \mathrm{p} \leq 0.00)$, engaged living $(\mathrm{r}=0.35$; $\mathrm{p} \leq 0.00)$, belief-in-others $(\mathrm{r}=0.29 ; \mathrm{p} \leq 0.00)$ and emotional competence $(\mathrm{r}=0.09$; $\mathrm{p} \leq 0.00)$ (see Table 6).

Table 6

Correlation of adolescents' social emotional health (SEHS-S) and self-esteem (N=935)

\begin{tabular}{cccccc}
\hline SEHS-S & $\begin{array}{c}\text { Belief- } \\
\text { in-self }\end{array}$ & $\begin{array}{c}\text { Belief- } \\
\text { in-others }\end{array}$ & $\begin{array}{c}\text { Emotional } \\
\text { competence }\end{array}$ & $\begin{array}{c}\text { Engaged } \\
\text { living }\end{array}$ & $\begin{array}{c}\text { General } \\
\text { index }\end{array}$ \\
\hline Self-esteem & $0.38^{* *}$ & $0.29^{* *}$ & $0.09^{* *}$ & $0.35^{* *}$ & $0.39^{* *}$ \\
\hline
\end{tabular}

Note. ${ }^{* *} p \leq 0.000$

To examine the relationship and influence of independent variables on the dependent variable, i.e., on adolescent social emotional health, a regression analysis on the data was performed which tested various models to identify the most suitable one. It was determined that adolescents' empathic concern, perspective-taking, personal distress, and self-esteem had an impact on their overall social emotional health. The formula for a regression line is as follows:

$$
\mathrm{Y}=86.232+0.665^{\star} \mathrm{X} 1+1.276^{*} \mathrm{X} 2+0.486^{\star} \mathrm{X} 3+0.614^{*} \mathrm{X} 4 \text {, }
$$

where $\mathrm{Y}=$ social emotional health, $\mathrm{X} 1=$ self-esteem, $\mathrm{X} 2=$ empathic concern, $\mathrm{X} 3=$ perspective-taking, and $\mathrm{X} 4=$ distress. 
The coefficient of determination $\left(\mathrm{R}^{2}\right)$ for this model is 0.36 . $\mathrm{Y}$ is significantly more influenced by the variable X2 (its standardized Beta value is 1.276) than by others: for $\mathrm{X} 1$ the standardized Beta value is 0.665 ; for $\mathrm{X} 3$ it is 0.486 ; and for $\mathrm{X} 4$ it is -0.614 .

The confirmatory factor analysis aimed to test the construct validity of the adolescent social emotional health survey (SEHS-S). Its first stage focused on testing the appropriateness of the SEHS-S questionnaire model, which consists of 12 latent (12 sub-scales loaded on to the four dispositions - belief-in-self, belief-in-others, emotional competence, and engaged living - and 36 observed factors (questionnaire statements/questions). The obtained results confirmed the structure of the questionnaire: $\chi^{2}(\mathrm{DF}=528, \mathrm{~N}=935)=2411.78, \mathrm{p}>0.05 ; \mathrm{RMSEA}=0.062 ; \mathrm{SRMR}=0.06$; $\mathrm{CFI}=0.93 ; \mathrm{NFI}=0.91$; and $\mathrm{GFI}=0.92$.

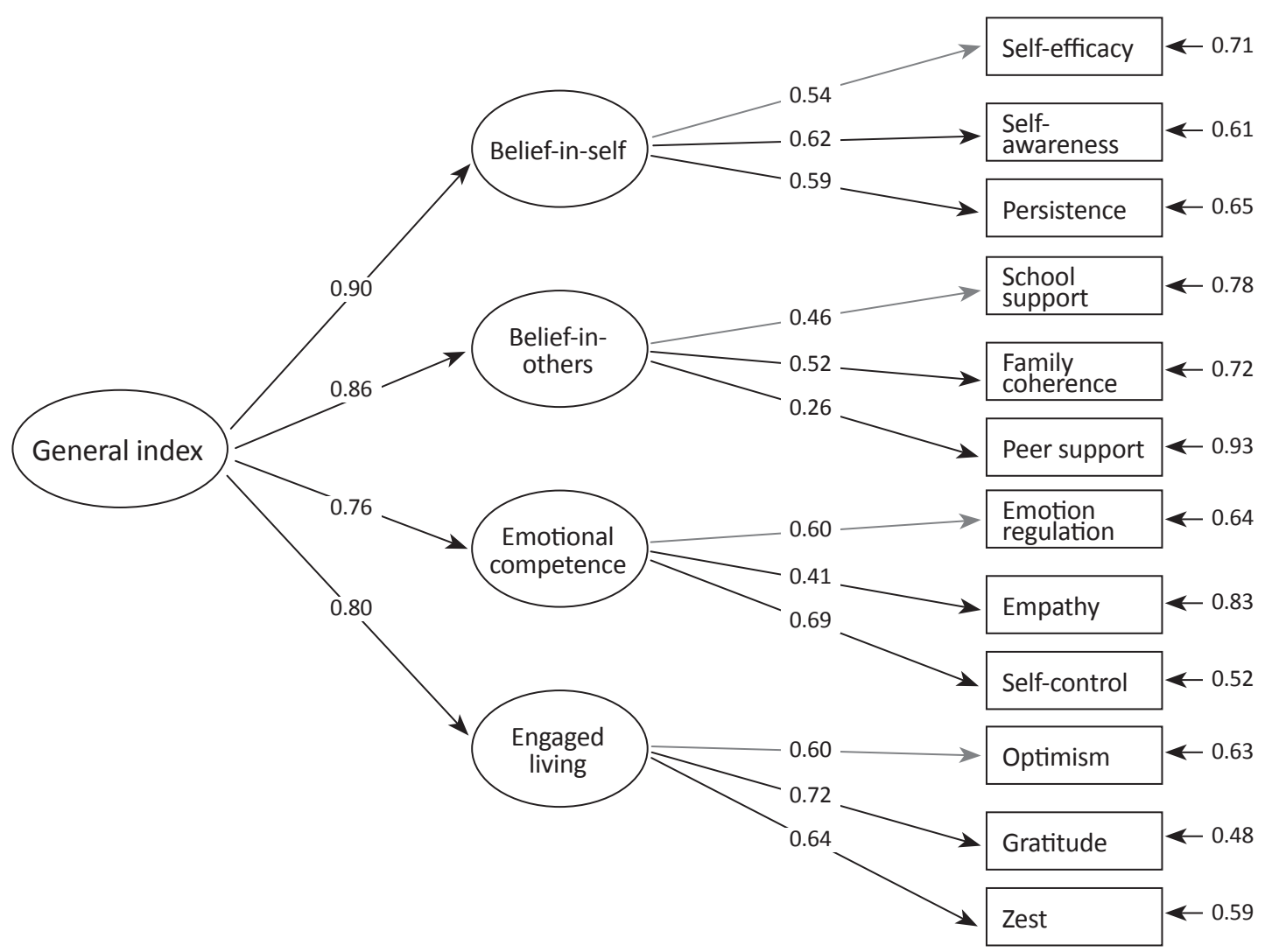

Figure 1. Social Emotional Health Survey-Secondary (SEHS-S) measurement model in a Lithuanian sample.

In the second stage, 12 sub-factors as measured variables (self-efficacy, selfawareness, persistence, school support, family coherence, peer support, emotion regulation, empathy, self-control, optimism, gratitude, zest) and four latent factors (belief-in-self, belief-in-others, emotional competence, engaged living) were employed. The degree of model fit was assessed using several criteria, the combination of which brought informed judgments about the overall adequacy of the model fit: $\chi^{2}(\mathrm{DF}=50, \mathrm{~N}=935)=351.64, \mathrm{p}>0.05$; the standardized root-mean-square error of approximation (RMSEA) $=0.079$; standardized root mean square residual $(\mathrm{SRMR})=0.053$; comparative fit index $(\mathrm{CFI})=0.94$; normed fit index $(\mathrm{NFI})=0.95$; and goodness of fit index $(\mathrm{GFI})=0.94$. 


\section{Discussion}

The data resulting from the SEHS-S taken by the 12-18 year-old Lithuanian adolescents presented in this study coincide with the results obtained by M. Furlong et al. (2014) and S. Lee et al. (2015), and with those from the previous research by the authors of this article (Petrulyte \& Guogienè, 2018).

The data obtained only partially corresponded to the data acquired by $\mathrm{T}$. Timofejeva, G. Svence, and A. Petrulyte (2016). The statistically significant difference in adolescents' social emotional health (SEHS-S) in terms of age and gender are in line with trajectories of adolescent development: a growing need for peer support and independence. The adolescent girls' emotional competence, self-confidence, and social relations are higher, whereas activity, sports, and other social competencies are better expressed in the group of boys (Cheng \& Chan, 2004; Way \& Greene, 2006; Mayer, Salovey, Caruso, \& Sitarenios, 2001; Petrides, Frederickson, Sangareau, \& Furnham, 2004; Petrides, Frederickson, Sangareau, \& Furnham, 2006; Pukinskaite, 2006; Strayer \& Roberts, 2004; Katyal et al., 2005, Schulte-Rüther et al., 2008; Furlong, et al, 2014; Žukauskienè et al., 2011). These results allow us to conclude that girls tend to attach more importance to interpersonal relations and emotions in socialization than do boys.

The present research has not disclosed any statistically significant differences in adolescents' self-esteem according to age, but the self-esteem of adolescent boys was higher than that of adolescent girls. When analyzing adolescents' self-esteem in terms of gender and age, it can be noticed that a considerable number of research studies on gender- and age-related differences in self-esteem have been conducted over the last two decades (Feingold, 1994; Kling, Hyde, Showers, \& Buswell, 1999; Orth, Robins, \& Widaman, 2012; Orth, Trzesniewski, \& Robins, 2010; Robins et al., 2002; Shaw, Liang, \& Krause, 2010; Trzesniewski, Donnellan, \& Robins, 2003; Twenge \& Campbell, 2001; Orth, Robins, \& Roberts, 2008; Mares, Leeuw, Scholte, \& Engels, 2010; Kularski, 2010; Buhrmester, Blanton, \& Swann, 2011), which have shown that men demonstrate higher levels of self-esteem than women. This gender-based difference appears in adolescence and continues throughout early and middle adulthood until it declines and even disappears in old age (Kling, et al., 1999; Robins, et al., 2002; Zeigler-Hill \& Myers, 2012). Other authors claim that the self-esteem of girls and boys does not statistically differ (Galambos, Barker \& Krahn, 2006; Tam, Lee, Har, \& Pook, 2011; Orth, Maes, \& Schmitt, 2015). Thus, slightly contradictory results are available.

The positive correlations between the dimensions of adolescents' social emotional health and empathy, as well as positive correlations with self-esteem revealed in the present research, are in line with the data of other studies on the development of emotional competence of mental health, emotional intelligence, and self-esteem and correlations of these dimensions (Petrides et al., 2006; Hoffman, 2000; Marsh, Parada, \& Ayotte, 2004; Kradin, 2005; Carr et al., 2005; Abbas, 2011; Petrulytè \& Guogienè, 2017, 2018).

The findings of the regression analysis and confirmatory factor analysis supported the use of the SEHS-S as a valid and reliable measurement instrument in mental health research with Lithuanian adolescents. The results replicated the findings reported in previous studies (Telef \& Furlong, 2017). The results of the re- 
gression analysis revealed the main factors predicting adolescent social emotional health: empathic concern, perspective-taking, self-esteem, and personal distress (negative). Similar results were obtained in other studies as well (Stern \& Cassidy, 2017; Telef \& Furlong, 2017).

\section{Limitations and future research}

The research presented in this article possesses some limitations: the authors of the methodology conducted their research with much larger groups of respondents (Furlong et al., 2014), whereas the sample size of the respondents is smaller in the present study. The age norms for the use of the SEHS-S survey have not been specified in Lithuania yet, and this is the initial stage of SEHS-S survey adaptation procedures in Lithuania. More precise support for the methodology would require a much wider survey of respondents from Lithuanian cities and regions, including not only general and secondary schools, but also other types of educational institutions; we need to produce exploratory factor analysis and collect information about adolescents' academic achievement, their observable school and family behavior, and their participation in class activities.

In our opinion, in future research, after all the validation and adaptation of the SEHS-S as a tool in Lithuania, it would be necessary to identify a risk group of adolescents with a low SEHS-S general index, as well as a group with potentially high scores. This could enable school counsellors to work on specific measures to facilitate improvement in the indicators in the group with a low SEHS-S general index, as well as to provide more opportunities for the development of the group with the high SEHS-S index. School psychologists will be able to apply the version adapted for Lithuania in monitoring the mental health of adolescents.

\section{Conclusions}

First, the self-esteem of adolescent boys was higher than that of adolescent girls, but the analysis of the adolescents' self-esteem did not reveal any statistically significant differences in terms of age (younger and senior adolescents).

Second, the correlation analysis allowed us to conclude that the social emotional health (SEHS-S) dispositions of adolescents positively correlate with self-esteem: belief-in-self $(\mathrm{r}=0.38 ; \mathrm{p} \leq 0.01)$; belief-in-others $(\mathrm{r}=0.29 ; \mathrm{p} \leq 0.01)$; engaged living $(\mathrm{r}=0.35 ; \mathrm{p} \leq 0.01)$; and social emotional health in general $(\mathrm{r}=0.39, \mathrm{p} \leq 0.01)$. The sub-scales of empathic concern, perspective-taking, and empathy index positively correlate with all the dispositions of SEHS-S ( $\mathrm{p} \leq 0.01$ ), whereas fantasy (IRI) and personal distress (IRI) demonstrated positive correlation only with the scale of emotional competence (SEHS-S) $(\mathrm{r}=0.22 ; \mathrm{p} \leq 0.01)$.

Third, the regression analysis of the research data allowed us to select the model where the impact of independent variables was most significant. The strongest social and emotional health predictors included empathic concern, self-esteem, and perspective-taking. Distress had a negative impact.

Fourth, the confirmatory factor analysis, conducted in two stages, confirmed the structural model of the Lithuanian version of the SEHS-S questionnaire. All the indices indicated a good model fit. 
On the basis of the research data, we can state that developing adolescents' empathy and self-esteem, and promoting their social emotional health, can be achieve at the same time, thus creating the prerequisites for positive development of young people into adulthood.

\section{References}

Abbas, I.A. (2011). Relationship between Emotional Intelligence and Self Esteem: study in universities of Pakistan. Arts and Design Studies. 1, 2011. Retrieved from https://www.academia. edu/1788454/A_Relationship_between_Emotional_Intelligence_and_Self_Esteem_study_in_ universities_of_Pakistan

Batson, C.D. (2009). These Things Called Empathy: Eight Related but Distinct Phenomena. In J. Decety \& W. Ickes (Eds.). The Social Neuroscience of Empathy. Cambridge: MIT press. https://doi.org/10.7551/mitpress/9780262012973.003.0002

Boyle, G.J., Saklofske, D.H., \& Matthews, G. (2014). (Eds.), Measures of personality and social psychological constructs. Elsevier/Academic Press.

Brown, T.A. (2015). Confirmatory Factor Analysis for Applied Research, Second Edition (Methodology in the Social Sciences). The Guilford Press.

Buhrmester, M.D., Blanton, H., \& Swann, W.B. Jr. (2011). Implicit self-esteem: Nature, measurement, and a new way forward. Journal of Personality and Social Psychology, 100, 365-385. https://doi.org/10.1037/a0021341

Carr, M.B., \& Lutjemeier, J.A. (2005). The relations of facial affect recognition and empathy to delinquency in youth offenders. Adolescence, 40(159), 601-19.

Cheng, S.T., \& Chan, A.C.M. (2004). A Brief Version of the Geriatric Depression Scale for the Chinese. Psychological Assessment, 16, 182-186. https://doi.org/10.1037/1040-3590.16.2.182

Čekanavičius, V. (2009). Statistika ir jos taikymai III [Statistics and its applications]. Vilnius, TEV.

Davis, M.H. (1980). A Multidimensional Approach to Individual Differences in Empathy. JSAS Catalog of Selected Documents in Psychology, 10, 85.

Decety, J., \& Cowell, J.M. (2014). The Complex Relation Between Morality and Empathy. Trends in Cognitive Sciences, 18(7), 337-339. https://doi.org/10.1016/j.tics.2014.04.008

Dutton, K.A., \& Brown, J.D. (1997). Global self-esteem and specific self-views as determinants of people's reactions to success and failure. Journal of Personality and Social Psychology, 73(1), 139-148. https://doi.org/10.1037/0022-3514.73.1.139

Feingold, A. (1994 ). Gender differences in personality: A meta-analysis. Psychological Bulletin, 116, 429-456. https://doi.org/10.1037//0033-2909.116.3.429

Furlong, M.J., You, S., Renshaw, T.L., Smith, D.C., \& O'Malley, M.D. (2014). Preliminary Development and Validation of the Social and Emotional Health Survey for Secondary Students. Social Indicators Research, 117, 1011-1032. https://doi.org/10.1007/s11205-013-0373-0

Furlong, M.J. (2015). Social Emotional Health Survey System. University of California, Santa Barbara Center for School-Based Youth Development Counselling, Clinical, and School Psychology Department. Retrieved from http://www.michaelfurlong.info/social-emotional-health.html

Galambos, N.L., Barker, E.T., \& Krahn, H.J. (2006). Depression, self-esteem, and anger in emerging adulthood: Seven-year trajectories. Developmental Psychology, 42, 350-365. https://doi.org/10.1037/0012-1649.42.2.350

Hoffman, M.L. (2000). Empathy and Moral Development: Implications for Caring and Justice. New York University. Cambridge University Press. https://doi.org/10.1017/СBO9780511805851

Ito, A., Smith, D.C., You, S., Shimoda, Y., \& Furlong, M.J. (2015). Validation and Utility of the Social Emotional Health Survey-Secondary for Japanese Students. Contemporary School Psychology, 19, 243-252. https://doi.org/10.1007/s40688-015-0068-4

Kalpokiené, V. (2005). Paauglių raida ir psichikos sutrikimai Ego psichologijos požiūriu [An Attitude of Ego Psychology Towards Development and Mental Disorders of Adolescents]. Psichologija, 31, 75-85. https://doi.org/10.15388/Psichol.2005..4337 
Katyal, S., \& Awasthi, E. (2005). Gender Differences in Emotional Intelligence Among Adolescents of Chandigarh. Journal of Human Ecology, 17, 153-155. https://doi.org/10.1080/09709274.2005.11905771

Kling, K.C., Hyde, J.S., Showers, C.J., \& Buswell, B.N. (1999). Gender differences in self-esteem: A meta-analysis. Psychological Bulletin, 125, 470-500. https://doi.org/10.1037/0033-2909.125.4.470

Kradin, R. (2005). The Roots of Empathy and Aggression in Analysis. Journal of Analytical Psychology. 50(4), 431-449. https://doi.org/10.1111/j.0021-8774.2005.00547.x

Kularski, C., (2010). Gender differences in self-esteem. Retrieved from https://www.academia.edu/1141988/Gender_Differences_in_Self_Esteem

Lee, S., You, S., \& Furlong, M.J. (2015).Validation of the Social Emotional Health Survey for Korean School Students. Child Indicators Research, 9(1), 73-92. https://doi.org/10.1007/s12187-014-9294-y

Mares, S.H.W., De Leeuw, R.N.H., Scholte, R.H.J., \& Engels, R.C.M.E. (2010). Facial attractiveness and self-esteem in adolescence. Journal of Clinical Child \& Adolescent Psychology, 39(5), 627-637. https://doi.org/10.1080/15374416.2010.501292

Marsh, H.W., Parada, R.H., \& Ayotte, V. (2004) A Multidimensional Perspective of Relations Between Self-Concept (Self-Description Questionnaire II) and Adolescent Mental Health (Youth Self-Report). Psychological Assessment, 16(1), 27-41. https://doi.org/10.1037/1040-3590.16.1.27

Mayer, J.D., Salovey, P., Caruso, D.L., \& Sitarenios, G. (2001). Emotional Intelligence as a Standard Intelligence. Emotion, 1(3), 232-42. https://doi.org/10.1037//1528-3542.1.3.232-242

Orth, U., Maes, J., \& Schmitt, M. (2015). Self-Esteem Development Across the Life Span: A Longitudinal Study with a Large Sample from Germany. Developmental Psychology, 51(2), 248-259. https:// doi.org/10.1037/a0038481

Orth, U., Robins, R.W., \& Roberts, B.W. (2008). Low self-esteem prospectively predicts depression in adolescence and young adulthood. Journal of Personality and Social Psychology, 95(3), 695-708. https://doi.org/10.1037/0022-3514.95.3.695

Orth, U., Robins, R.W., \& Widaman, K.F. (2012). Life-span development of self-esteem and its effects on important life outcomes. Journal of Personality and Social Psychology, 102, 12711288. https://doi.org/10.1037/a0025558

Orth, U., Trzesniewski, K.H., \& Robins, R.W. (2010). Self-esteem development from young adulthood to old age: A cohort-sequential longitudinal study. Journal of Personality and Social Psychology, 98, 645-658. https://doi.org/10.1037/a0018769

Park, N., \& Peterson, Ch. (2008). Positive Psychology and Character Strengths: Application to Strengths-Based School Counselling. Professional School Couseling, 12(2), 85-92. https://doi.org/10.5330/PSC.n.2010-12.85

Petrides, K.V., Frederickson, N., \& Furnham, A. (2004). The Role of Trait Emotional Intelligence in Academic Performance and Deviant Behavior at School. Personality and Individual Differences, 36, 277-293. https://doi.org/10.1016/S0191-8869(03)00084-9

Petrides, K.V., Frederickson, N., Sangareau, Y., \& Furnham, A. (2006). Trait Emotional Intelligence and Children's Peer Relations at School. Social Development, 15(3), 537-547. https://doi.org/10.1111/j.1467-9507.2006.00355.x

Petrulyté, A., \& Guogiené, V. (2017). Paauglių psichologinès sveikatos stiprinimas, vykdant tiriamąją ir prevencinę veiklą mokykloje [Enhancement of Adolescents' Psychological Health Using Investigative and Preventive Activities at School]. Pedagogika, 126(2), 99-114. https://doi.org/10.15823/p.2017.22

Petrulyte, A., \& Guogiene, V. (2018). Adolescents' social emotional health and empathy in a Lithuanian sample. International Journal of Psychology: Biopsychosocial Approach, 22. https://doi.org/10.7220/2345-024X.22.4

Project Covitality (2018). UC Santa Barbara, International Center for School-Based Youth Development. Retrieved from https://www.project-covitality.info

Pukinskaitè, R. (2006). Empatijos ir psichosocialinio funkcionavimo ypatybès paauglystejje [Empathy and Psychosocial Functioning in Adolescence]. Socialinis darbas. 5(2), 55-62.

Pukinskaite, R., \& Guogiene, V. (2010). Vyresniuju paaugliu pykcio ekspresijos ir kontroles bei psichosocialiniu sunkumu analize [Analysis of Anger Expression and Control and Psychosocial Problems in Older Adolescents]. Visuomenes sveikata, 2(49), 104-113. 
Ramanauskienè, T., Matulionienė, V., \& Martinkienė, V. (2002) Paauglių depresiškumas ir savižudybės pavojus (lyginamoji analizè Klaipėdos, Kauno ir Šiaulių miestuose). [Depressive Symptoms and Threat of Suicide Among Adolescents (Comparative Analysis in Klaipėda, Kaunas and Šiauliai)]. Medicina, 38(4), 393-397.

Robins, R.W., Trzesniewski, K.H., Tracy, J.L., Gosling, S.D., \& Potter, J. (2002). Global self-esteem across the life span. Psychology and Aging, 17, 423-434. https://doi.org/10.1037/0882-7974.17.3.423

Rosenberg, M. (1989). Society and the adolescent self-image. Revised edition. Middletown, CT: Wesleyan University Press.

Rosenthal, S.A., Matthew Montoya, R., Ridings, L.E., Rieck, S.M., \& Hooley, J.M. (2011). Further evidence of the Narcissistic Personality Inventory's validity problems: A meta-analytic investigation - Response to Miller, Maples, and Campbell (this issue). Journal of Research in Personality, 45, 408-416. https://doi.org/10.1016/j.jrp.2011.06.004

Schutte, N.S., Malouff, J.M., Simunek, M., Hollander, S., McKenley, J., \& Hollander, S. (2002) Characteristic emotional intelligence and emotional well-being. Cognition and Emotion. 16(2), 769-78. https://doi.org/10.1080/02699930143000482

Schulte-Rüther, M., Markowitsch, H.J., Shah, N.J., Fink, G.R., \& Piefke, M. (2008). Gender differences in brain networks supporting empathy. NeuroImage, 42(1), 393-403. https://doi.org/10.1016/j.neuroimage.2008.04.180

Shaw, B.A., Liang, J., \& Krause, N. (2010). Age and race differences in the trajectories of self-esteem. Psychology and Aging, 25, 84-94. https://doi.org/10.1037/a0018242

Stern, J.A., \& Cassidy, J. (2017). Empathy from infancy to adolescence: An attachment perspective on the development of individual differences. Developmental Review, 47, 1-22. https://doi.org/10.1016/j.dr.2017.09.002

Strayer, J., \& Roberts, W. (2004). Children`s Anger, Emotional Expressiveness, and Empathy: Relations with Parents ' Empathy, Emotional Expressiveness, and Parenting Practices. Social development, 13(2), 229-254. https://doi.org/10.1111/j.1467-9507.2004.000265.x

Tam, C.L., Lee, T.H., Har, W.M., \& Pook, W.L. (2011). Perceived Social Support and Self-Esteem Towards Gender Roles: Contributing Factors in Adolescents. Asian Social Science 7(8), 49-58. https://doi.org/10.5539/ass.v7n8p49

Telef, B.B., \& Furlong, M.J. (2017). Adaptation and Validation of the Social and Emotional Health Survey-Secondary into Turkish Culture. International Journal of School and Educational Psychology, 5(4), 255-265. https://doi.org/10.1080/21683603.2016.1234988

Timofejeva, T., Svence, G., \& Petrulyte, A. (2016). Theoretical and Practical Study of the Concept of Social and Emotional Health by Michael J. Furlong and Applied to the Selection of Teenagers and Youth. Problems of Psychology in the 21st Century, 10 (2), 98-107.

Trzesniewski, K.H., Donnellan, M.B., \& Robins, R.W. (2003). Stability of selfesteem across the life span. Journal of Personality and Social Psychology, 84, 205-220. https://doi.org/10.1037/0022-3514.84.1.205

Twenge, J.M., \& Campbell, W.K. (2001). Age and birth cohort differences in self-esteem: A cross-temporal meta-analysis. Personality and Social Psychology Review, 5, 321-344. https://doi.org/10.1207/S15327957PSPR0504_3

Valantinas, A. (2009). Socialinis emocinis ugdymas. Kas tai? Kuo gali mums padèti? [Social Emotional Education: What is It? How can it Help Us?] Švietimo problemos analizè, 10(38). Retrieved from http://www.nmva.smm.lt/wp-content/uploads/2012/12/Socialinisemocinisugdymas.-Kas-tai-Kuo-gali-mums-pad\%C4\%97ti-2009-gruodis.pdf

Way, N., \& Greene, M. (2006). Trajectories of Perceived Friendship Quality during Adolescence: The Patterns and Contextual Predictors. Journal of Research on Adolescence, 16(2), 293-320. https://doi.org/10.1111/j.1532-7795.2006.00133.x

You, S., Furlong, M., Felix, E., \& O'Malley, M. (2015). Validation of the Social and Emotional Health Survey for Five Sociocultural Groups: Multigroup Invariance and Latent Mean Analyses. Psychology in the Schools, 52(4), 349-362. https://doi.org/10.1002/pits.21828

Zeigler-Hill, V., \& Myers, E.M. (2012). A review of gender differences in self-esteem. In S.P. McGeown (Ed.), Psychology of gender differences, Hauppauge, NY, US: Nova Science Publishers, 131-143. 
Žukauskienė, R., Malinauskienè, O., \& Erentaitė, R. (2011). Tëvų auklejjimo stiliaus ir emocinio intelekto sąsajos su vyresniųjų paauglių saviveiksmingumu bei saviverte pagal lytį [Effects of Parenting Styles and Emotional Intelligence on Self-Efficacy and Self-Esteem in Late Adolescence: Gender Differences]. Psichologija, 44, 22-41. https://doi.org/10.15388/Psichol.2011.44.2550

Original manuscript received September 27, 2019

Revised manuscript accepted November 10, 2019

First published online December 25, 2019

To cite this article: Petrulytè, A., Guogienè, V., Rimienè, V. (2019). Adolescent Social Emotional Health, Empathy, and Self-esteem: Preliminary Validation of the Lithuanian Version of the SEHS-S Questionnaire. Psychology in Russia: State of the Art, 12(4), 196-209. DOI: 10.11621/pir.2019.0412 